\title{
Resgatando a história da psiquiatria
}

\author{
Retrieving the history of psychiatry
}

\author{
Flávio Shansis* \\ * Editor, Rev Psiquiatr RS.
}

Recentemente, neste ano de 2007, Goodwin \& Jamison lançaram a segunda edição de seu livro Manic-depressive illness ${ }^{1}$. Desde sua primeira tiragem, a publicação tem sido um marco para todos os psiquiatras e, em especial, para aqueles que se dedicam ao que hoje consideramos transtornos de humor bipolar (THB). Mais do que apresentar informações atualizadas sobre o tema, chama a atenção, desde a primeira edição, a ênfase desses autores no resgate histórico. Nesse caso, do resgate histórico do conceito de doença maníaco-depressiva. Goodwin \& Jamison retomam o conceito kraepeliano já no título de sua obra, ao deixar claro que manic-depressive illness engloba não apenas o que hoje entendemos por THB mas também as depressões recorrentes. Estas, pelos sistemas classificatórios atuais, fariam parte dos chamados transtornos unipolares de humor.

O que poderia ser apenas uma discussão conceitual, ao nosso ver é bem mais do que isso. Esses autores norte-americanos resgatam um passado de tradição da psiquiatria européia e, com isso, questionam os próprios manuais de classificação atualmente utilizados. Indiretamente, acusam o esquecimento que a psiquiatria contemporânea faz de seu passado ao "fatiar" diagnósticos ao invés de compreendê-los dentro de uma coerência psicopatológica (o que tem acarretado uma freqüência aumentada e questionável das chamadas “comorbidades"). Esse é, portanto, o grande mérito desses autores ao enfatizarem a necessidade de sempre buscarmos na própria história respostas para os dilemas atuais. Não raro, "a roda já estava inventada". Em tempos de fast food, a sociedade informatizada esqueceu que o mundo não iniciou quando o homem chegou à lua. A psiquiatria atual, de forte orientação norte-americana, por seu lado, teima em acreditar que não havia "vida inteligente" antes dos assim chamados DSMs (Diagnostic and Statistical Manuals of Mental Disorders).

Em 1899, Emil Kraepelin², na introdução de seu clássico livro-texto, já fazia uma observação fundamental para os que pretendiam dedicar sua vida aos cuidados dos insanos. Ele disse: "Aqueles que tratam e estudam doença mental devem, primeiro, da observação à beira do leito, delinear as formas clínicas da doença; eles devem definir e predizer o seu curso, determinar suas causas e descobrir como melhor tratar e, então, por último, prevenir a insanidade". Nós sabemos que os alienistas, ao conviverem muito de perto com seus pacientes, puderam observar e descrever a evolução de muitos transtornos psiquiátricos. Se lhes faltavam recursos terapêuticos à época, não lhes faltava acurácia clínica, e sobrava-lhes brilho intelectual.

Os escritos hipocráticos, como A natureza do homem (de 400 a.C.), já demonstravam uma teoria humoral das variações do humor, como a bile negra e a amarela. O pensamento aristotélico valorizava o coração mais do que o cérebro como o órgão disfuncional na melancolia. Arateus da Cappadocia (século II d.C.) fez descrições brilhantes de quadros maníacos, que foram elaboradas e compiladas por Galeno de Pergamo (131 a 201 d.C.). Até a Idade Média, manteve-se o conceito clássico greco-romano de que as aflições físicas e mentais estariam sob cuidados médicos. Foi quando a "idade das trevas" medieval levou para a igreja católica o domínio das doenças. Felizmente, muitos documentos fundamentais não foram queimados graças ao trabalho corajoso de médicos como Avicenna (em torno de 1000 d.C.). No século XIX, e já antes, as escolas francesa (Pinel, Esquirol, Falret, Baillarger) e alemã (Kraepelin, Griesinger) contribuíram de forma inequívoca para o desenvolvimento da psiquiatria. E é nesse contexto histórico que surge a psiquiatria brasileira: tão jovem quanto nosso país.

A história tenta nos ajudar a compreender nossas imperfeições. Olhar para o nosso passado como nação e para o de nossa especialidade pode nos auxiliar a tolerar melhor nossas limitações. Mas pode também nos capacitar a refazer caminhos tomados, muitas vezes, de forma discutível. Tem ficado evidente que a psiquiatria 
tem necessitado se repensar. Tem ficado igualmente evidente que a psiquiatria brasileira também o necessita. No último número de nossa revista, colocamos nosso olhar para o futuro, tentando predizer o que teremos à frente na especialidade. Neste, voltamos nossos olhos ao passado, tentamos compreender os atuais caminhos e descaminhos da psiquiatria brasileira buscando respostas desde seus tempos primeiros.

A Revista de Psiquiatria do Rio Grande do Sul mais uma vez reafirma que a história da psiquiatria ocupa uma parte importante de sua linha editorial. É chegado o momento de resgatarmos ainda mais a história da psiquiatria brasileira. Que ela possa nos auxiliar na busca de soluções para um sistema público de saúde que tanto tem feito sofrer aqueles que padecem de doenças mentais.

\section{Referências}

1. Goodwin FK, Jamison KR. Manic-depressive illness: bipolar disorders and recurrent depression. 2nd ed. New York: Oxford University; 2007.

2. Kraepelin E. Manic depressive insanity and paranoia. Edinburgh: Livinsgtone; 1921. 